Western North American Naturalist 68(2), (C) 2008, pp. 210-224

\title{
LEECHES OF THE SNAKE RIVER IN IDAHO AND OREGON: PALEODRAINAGE IMPLICATIONS OF MOOREOBDELLA MICROSTOMA
}

\author{
Peter Hovingh ${ }^{1}$, William H. Clark ${ }^{2,3}$, and John Keebaugh ${ }^{3}$
}

\begin{abstract}
Leech species of the mid-Snake River of Idaho and Oregon are described, and the distribution of the extant leech Mooreobdella microstoma Moore in the Snake River paleodrainage is delineated. Samples were collected from aquatic surveys in the Snake River using suction dredging by the Idaho Power Company and U.S. Bureau of Reclamation between 1995 and 2006. Supplementing these surveys, opportunities were provided for leech identification in water-quality analyses in Arizona and Wyoming and in other surveys in California, Oregon, Washington, and Idaho. Eight species of leeches were found in the Snake River surveys. Erpobdella parva Moore was the most widely distributed species, occurring both above and below Shoshone Falls. Mooreobdella microstoma was widely distributed below Shoshone Falls. Other leech species were rare, although Helobdella stagnalis Linnaeus was very common above and less common below Shoshone Falls, a natural barrier to the anadromous fish. Mooreobdella microstoma is an extant species that links the Snake River to the lower Colorado River by various paleodrainages. It probably colonized the Snake River by upstream movement, whereas Erpobdella parva likely colonized this river by downstream movement.
\end{abstract}

Key words: Snake River, leeches, Hirudinea, Mooreobdella microstoma, Erpobdella parva, paleodrainage, natural barriers, zoogeography.

Few large rivers have been surveyed extensively for macroinvertebrates and still fewer for leeches in the western United States. Macroinvertebrates from sand runs, sand beaches, and backwaters (Jordan et al. 1999) and cobble, soft sediments of pools, and drift (Hayden et al. 2003) of the Green River and Colorado River through Canyonlands National Park were reported for periods of high and low flow. A study on the Fraser River showed that during high flows the macroinvertebrate populations shifted to more shallow reaches (Rempel et al. 1999). Leeches were not noted in these surveys. McCabe et al. (1997) reported benthic invertebrates, including leeches (species unidentified), in the Lower Columbia River. Becker and Dauble (1979) reported leeches in the lower Columbia River.

In contrast to the lack of leeches in the Green, Colorado, and Fraser rivers, the Snake River of the Columbia River basin has a rich leech fauna. For many years the Idaho Power Company (Clark et al. 2005), Bureau of Reclamation (Irizarry 1999), Idaho Division of Environmental Quality (Grafe 2002), and the Environmental Protection Agency (Peck et al. 2003) have sampled the Snake River in Idaho for macroinvertebrates to satisfy a variety of ob- jectives. Stanford (1942) was the first to report on the aquatic biological condition of the Snake River. This paper reports on the identification and distribution of leeches in the Snake River from these previous efforts. The presence of the leech Mooreobdella microstoma below Shoshone Falls is discussed in terms of its continental distribution and the history and paleodrainages of the Snake River.

\section{Geological Setting of the Snake River in Idaho}

The Snake River flows from western Wyoming through southern Idaho, eastern Oregon, and southwestern Washington, where it joins the Columbia River and flows to the Pacific Ocean. The Snake River has the steepest gradient in North America of any large river, and its path in southern Idaho lies within the Snake River Plain, a geographic feature that stands out topographically in the Intermountain region. The course of the river in Idaho has been dictated by rifts and volcanic activity, unlike most rivers where the course is set by erosional processes. In the description of the Snake River that follows, Ma denotes million years ago and Ka denotes thousand years ago.

\footnotetext{
1721 2nd Avenue, Salt Lake City, UT 84103. E-mail: phovingh@xmission.com

2Idaho Power Company, Box 70, Boise, ID 83707.

${ }^{3}$ Orma J. Smith Museum of Natural History, The College of Idaho, Caldwell, ID 83605.
} 
The Snake River Plain has largely a volcanic history. The Yellowstone hot spot from the McDermitt caldera near the Nevada-Oregon border moved northeast $16 \mathrm{Ma}$, passing north of Twin Falls 10.8 Ma, the Picabo field 10.2 Ma, the Heise Field 6.6-4.3 Ma, and the Yellowstone Field 2.06-0.6 Ma to its present-day location in northwestern Wyoming (Malde 1991, Pierce and Morgan 1992, Lanphere et al. 2002, Morgan and McIntosh 2005). The Nevada-Oregon rift extended from southern Nevada into Washington and passed near McDermitt and the lower Owyhee River, resulting in basaltic flows in the Steens Mountain-Malheur Gorge 16.6-15.3 Ma and the Columbia River group 16.1-15.0 Ma and cessation of activity by $10.5 \mathrm{Ma}$ (Christiansen and Yeats 1992, Zoback et al. 1994, Cummings et al. 2000, Hooper et al. 2002). These 2 geological features account for the confinement of the present Snake River in southern Idaho.

The western Snake River Plain formed from a southeastward-trending rift that gradually extended southeast to near Hagerman, Idaho. Volcanic and lacustrine deposits filled the western plain. The late Miocene Chalk Hills Formation is characterized by saline (gypsum) deposits (Repenning et al. 1995), suggesting a water body with limited outflows or inflows. The Glenns Ferry Formation and the associated lake occurred in the Pliocene, with the oldest formation dated about 4 Ma near Hagerman where a Kings Hill-Hagerman lake margin and the Snake River delta and marsh occurred. The lake margin moved westward to near Bruneau by $2.4 \mathrm{Ma}$ and to Froman Ferry (near the Oregon state border) about 1.7 Ma. Throughout the Glenns Ferry lake period, the fauna and flora were uniform, suggesting that this lake had both an outlet and a continuous existence. The outlet has flowed over a stepwise reduce sill through Hells Canyon into the Salmon River tributary of the Columbia River since 3.9 Ma. A major "outburst" at 2 Ma may have resulted from greater inflows from glaciers in the Yellowstone region between 2.4 and $2.1 \mathrm{Ma}$ and possibly from the Yellowstone Huckleberry Ridge caldera explosion at $2.06 \mathrm{Ma}$ (Malde 1991, Repenning et al. 1995, Lanphere et al. 2002). The Pleistocene Bruneau Formation resulted from basaltic flows from 2 to $1 \mathrm{Ma}$ that moved the Snake River channel south and west. Basaltic flows have blocked and diverted the Snake River from its historic channel in the lower Boise River (Malde 1991). The rift nature of the western Snake River Plain suggests that a major upsteam aquatic barrier occurred throughout the history of the Snake River, separating this section of river from the upper Snake River.

The eastern Snake River Plain was formed as a structural depression following the movement of the Yellowstone hot spot (Pierce and Morgan 1992) and is characterized by a lack of sediment (Malde 1991). Volcanic activity as recent as 2 Ka has occurred (Kuntz et al. 1986). Five river basaltic infills occurred between 0.5 $\mathrm{Ma}$ and $0.05 \mathrm{Ma}$. The inflow to the lake behind the McKinney basaltic dam was matched by an equal outflow through a porous dam and resulted in a stable lake shoreline (Malde 1982). The Sands Springs Basalt created a temporary lake near Burley, while the basaltic flow forced the Snake River south into its present channel between Hagerman and Twin Falls (Malde 1991).

$$
\begin{aligned}
& \text { Effects of the Bonneville } \\
& \text { and Spokane Floods }
\end{aligned}
$$

The Bonneville Flood occurred when a sill of Lake Bonneville in western Utah collapsed at $14.5 \mathrm{Ka}$, causing the $100-\mathrm{m}$ lowering of the lake. This flood water poured down the Snake River; the flow of water peaked at 1 millon $\mathrm{m}^{3} \cdot \mathrm{sec}^{-1}$ and may have lasted several months (Malde 1965, Jarrett and Malde 1987, Oviatt et al. 1992, O'Connor 1993). The lower Snake River in Washington and its Columbia River route to the Pacific Ocean were flooded more than 25 times between 19 and $13 \mathrm{Ka}$ by the Missoula (Spokane) floods. The glacial dams that blocked the Clarks Fork River in Montana repeatedly broke, releasing up to 10 times more water than the Bonneville flood (O'Conner 1993, Benito and O'Conner 2003). Other ice-dam lakes occurred both in recent times and in earlier glacier periods (Richmond et al. 1965).

\section{Paleodrainage of the Snake River}

Wheeler and Cook (1954) proposed, on the basis of physiography, that the paleodrainage of the Snake River passed through southeastern Oregon, through the Lahontan Basin, and to the Feather River in California. Taylor (1960) noted, on the basis of fossil and extant molluscan and fish species' distribution, that a route connected Utah and Bear Lakes in the Bonneville 
Basin with the Snake River, the Oregon basins, Klamath Basin, and western Lahontan Basin of Nevada and California. A Miocene connection was proposed between the Snake River and the Grand Valley (Sacramento-San Joaquin) drainage of California (Miller 1965, Taylor 1966, 1985; see Fig. 15 in Taylor 1985). A Pliocene route from Glenns Ferry lake to the Oregon basins, western Lahontan Basin, and Klamath Basin northwest to the Pacific was proposed, and drainages east and west of the present Sierra Nevada flowed south, either around the Sierra Nevada or within the Grand Valley (see Fig. 25 in Taylor 1985, see Fig. 5 in Taylor and Bright 1987). Hershler and Liu (2004) supported, in part, the route of Wheeler and Cook (1954), based on molecular phylogeny studies of Hydrobiidae snails.

The upper Snake River was disconnected from the lower Snake River from the Miocene into the Pliocene and has been shown to flow south into the Bonneville Basin and northward toward the Columbia River basin (Taylor 1985, Taylor and Bright 1987, Sadler and Link 1996). Taylor (1985) and Taylor and Bright (1987) noted that the late Pliocene and early Pleistocene "fish hook" fauna pattern was a result of a series of connections through time and space and not of a continuously flowing body of water. Recently, based on the presence of the fish Lepidomeda in the Virgin River (Colorado River basin) and its relative Synderichthys in the upper Snake River, Smith et al. (2002) proposed a connecting route through the Bonneville Basin.

Repenning et al. (1995) reexamined the literature and geology of the western Snake River Plain. They synchronized the geology with a more accurate chronology to reflect events in the Pacific region. This revision altered many previous interpretations, including Repenning's earlier works. They proposed that (1) the outflow of the Pliocene Glenns Ferry Snake River did not run through Oregon but through Hells Canyon by $3.5 \mathrm{Ma}$, and the Glenns Ferry lake for its lifetime drained into the Columbia River; and (2) the upper Snake River flowed south from Twin Falls to the Lahontan Basin, following much of the present course of the Humboldt River, west to the upper Pit River prior to $4 \mathrm{Ma}$ in late Miocene to early Pliocene (Repenning et al. 1995). The Klamath Lake region may have been a tributary of the Pit River drainage. This model accounts for the fish and molluscan fauna as well as the waterdependent mammalian microtine fauna (muskrats and voles). A more northern course of this paleo Snake River is depicted by Wagner et al. (1997). Volcanism altered this paleo Snake River route and diverted the flows into the present Snake River channel.

\section{Methods}

Leeches were collected as part of Snake River aquatic surveys by the Idaho Power Company between River Mile (RM) 210 and RM 600 following the standard protocol (Clark et al. 2005) with modifications in later sampling (Fore and Clark 2005). The surveys involved SCUBA divers who used a Venturi loop suction-dredge to sample quadrants 0.25$\mathrm{m}^{2}$ to water depths of $15 \mathrm{~m}$. Samples were processed for macroinvertebrate analysis, preserved with $70 \%$ ethanol, and sorted and identified by EcoAnalyst, Inc. (Moscow, ID). These studies have been ongoing since 1995 . The Bureau of Reclamation has surveyed RM 650-700 of the Snake River above Shoshone Falls including Lake Walcott. These surveys used Surber samplers and recently the Venturi loop suction-dredge. Other sampling in the Snake River has been done following methods of Grafe (2002) and Peck et al. (2003). Voucher specimens for these projects are housed in the Orma J. Smith Museum of Natural History (ALBRCIDA), The College of Idaho, Caldwell. Leech nomenclature follows Klemm (1985), Sawyer (1986), and Davies and Govedich (2001); it is based on anatomical features.

Information on the distribution of the leech Mooreobdella microstoma in the western United States was supplemented by additional institutional and private collections: Aquatic Biology Associates, Inc. (Corvallis, OR), including specimens, which now reside in the Orma J. Smith Museum, from various surveys in British Columbia, Montana, Washington, Oregon, California, and Wyoming (Wyoming Department of Environmental Quality); Arizona Department of Environmental Quality, specimens housed within that department; United States National Museum of Natural History (USNM), including the Mooreobdella collection from the Great Basin (P. Hovingh); Canada Museum of Nature; Academy of Natural Sciences at Philadelphia; Pinnacles National Monument, California, specimens collected by 


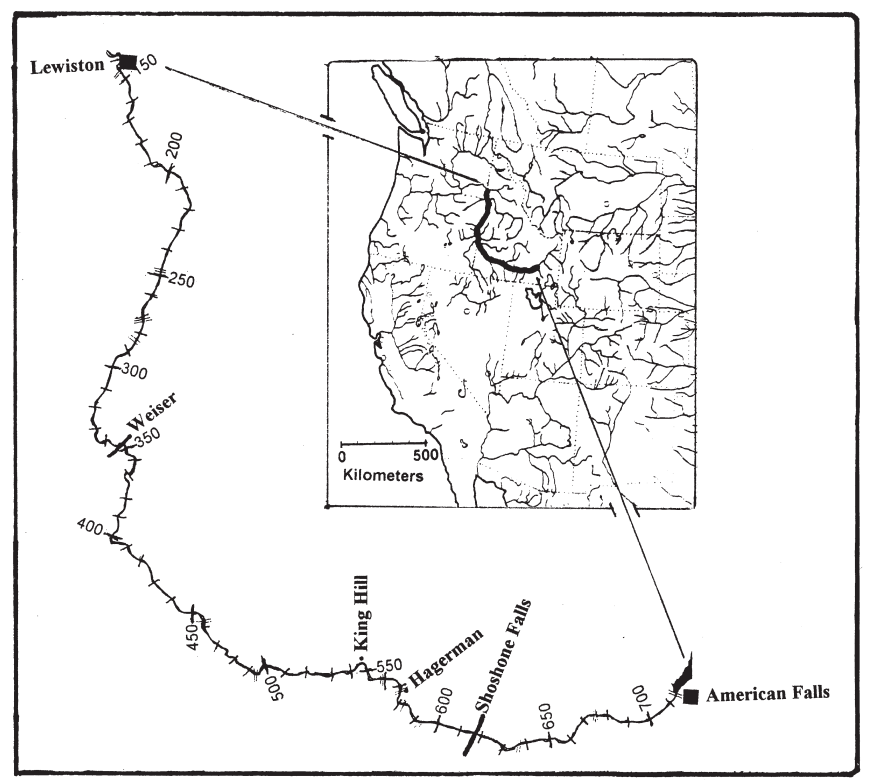

Fig. 1. The study region of the Snake River in Idaho and Oregon. Inset shows the Snake River study area (dark line) in relation to the Columbia River drainage and western United States. River miles $(\mathrm{RM} ; 1 \mathrm{mile}=1.609 \mathrm{~km})$, are denoted every 10 miles and labeled every 50 miles. The major barrier at Shoshone Falls is denoted with a thick line across the river at RM 618. The light double lines represent dams, with Lake Walcott dam occurring near RM 675. The region between Hagerman and Weiser is the western Snake River Plain. Below Weiser, the river flows through Hells Canyon.

Aquatic Biology Associates, Inc.; the amphibian parasite studies collected by $\mathrm{K}$. Lunde (see Johnson et al. 2002 for the map of collection sites); and specimens from Pahranagat Valley in southern Nevada collected by S. McKown. The facilities of the museums were utilized in examining their collections. The Great Basin (2374 sites, shown in Hovingh 2004a), Colorado River basin (856 sites), and Columbia River basin (548 sites) furnish supportive material from the western United States as well as negative sites for $M$. microstoma in much of the region (Hovingh 2004b, P. Hovingh unpublished data from a continuing project).

\section{RESUlts AND Discussion}

The region of the Snake River of Idaho study is shown in Figure 1. The probability of a leech occurring in an event $(n=1560)$ was 0.07 between RM 534 and 589. Leeches were identified as listed below.

\section{Family Glossiphoniidae}

Actinobdella inequiannulata Moore, found across southern Canada and the northern and eastern United States (Klemm 1985), was identified at 4 sites within RM 583-588 (Upper Salmon Falls Reservoir) and at 2 locations in Lake Walcott Reservoir (Fig. 2G). The locations in the Upper Salmon Falls Reservoir were up to $4.5 \mathrm{~m}$ deep, and specimens were taken by dredging sand, silt, mud, and fine substrate during spring (March-June). This fish leech was collected at The Dalles in Wasco County, Oregon, in 1994 (Water Quality Studies), and 6 specimens were collected from the largescale sucker, Catostomus macrocheilus, in the Hanford Reach of the Columbia River (Becker and Dauble 1979). The host is mostly the sucker family (Klemm et al. 2003) with 6 species (Catostomus ardens, C. catostomus, C. columbianus, C. discobolus, C. macrocheilus, and C. platyrhynchus) occurring in the Columbia River and Snake rivers (McPhail and Lindsey 1986).

Glossiphonia complanata (Linnaeus), with its Holarctic distribution and occurrences in Alaska, Canada, and the northern United States (Klemm 1985, Sawyer 1986), was identified at 3 sites within RM 576, 583, and 587 and 3 sites in Lake Walcott (Fig. 2D). In ongoing surveys this species was rarely found in 

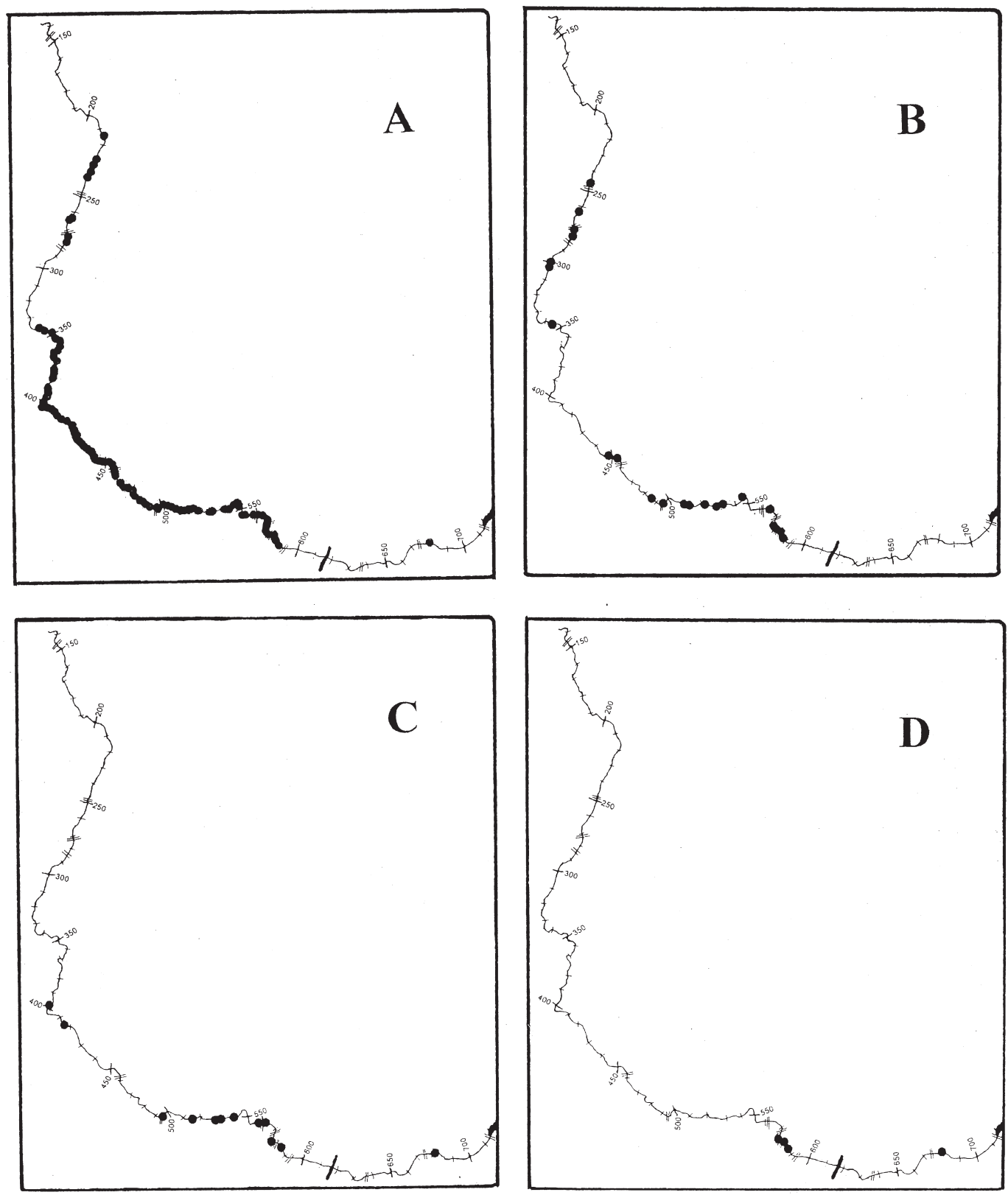

Fig. 2. Leech distribution in the Snake River (see Fig. 1 for details): A, Erpobdella parva; B, Mooreobdella microstoma; C, Helobdella stagnalis; D, Glossiphonia complanata; E, Piscicola sp.; F, Theromyzon sp.; G, Actinobdella inequiannulata; and $\mathrm{H}$, Placobdella montifera.

the Snake River reach below the Lake Walcott dam ( J. Keebaugh and P. Hovingh unpublished data). Specimens from between RM 276 and 587 were obtained between May and July by dredging to river depths of $0.3-4.0 \mathrm{~m}$ in sites having substrates of sand, silt, mud, and fines, as well as bedrock, whereas specimens from Lake Walcott were obtained in June and November. This leech feeds on macroinvertebrates.

Helobdella stagnalis (Linnaeus), of Holarctic distribution (Klemm 1985, Sawyer 1986), was 

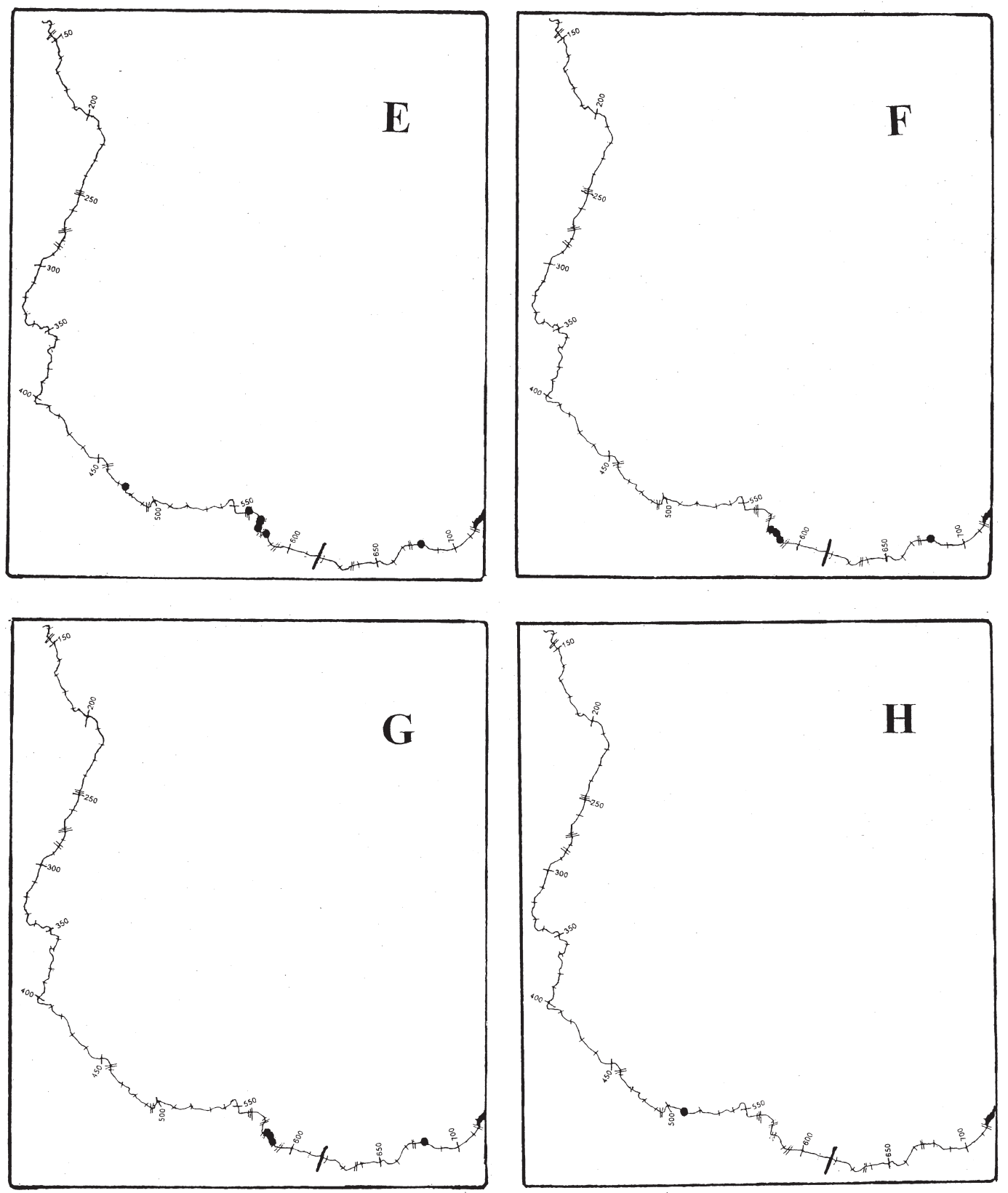

Fig. 2. Continued.

identified at 13 sites within RM 398-415, RM 495-585, and 7 areas of Lake Walcott (Fig. $2 \mathrm{C}$ ). This was the 2 nd most common leech in the Snake River reach below the Lake Walcott dam and above Shoshone Falls (J. Keebaugh and P. Hovingh unpublished data) and was noted in the Columbia River reach at Han- ford (Becker and Dauble 1979). This common leech feeds on macroinvertebrates.

Placobdella montifera Moore, found in eastern North America and west in the CanadaUnited States border states (Klemm 1985), was identified at 1 site at RM 511 in C.J. Strike Reservoir by dredging sand and silt to a depth 
of 2.4-3.1 $\mathrm{m}$ in April, where water temperature was $11.8^{\circ} \mathrm{C}$ (ALBRCIDA 07200; Fig. 2H). This little-known leech was collected from Okanagan Lake in July 1935 (USNM 40325), found in a survey in the Columbia River in October 1991 in Washington/Oregon (Aquatic Biology Associates, Inc), and reported from the Hanford reach of the Columbia River from a fingerling sucker (an immature leech) in October 1976 and from 1 adult in rocks in June (Becker and Dauble 1979). This leech may feed on amphibians, fish, and macroinvertebrates including mussels. Our specimen is a new state record for Idaho.

Theromyzon sp., a waterfowl leech taxon found in the northern United States, Canada, and Alaska as well as Eurasia (Klemm 1985, Davies and Govedich 2001), was found at 5 sites in RM 581-589 and 2 areas in Lake Walcott (Fig. 2F). Theromyzon was found in March and April by dredging 0.9-9.1 m deep in water having gravel, sand, silt, mud, and fines. The Theromyzon genus has undergone significant revision in North America and now includes 5 species (Davies and Govedich 2001) distinguishable by dissection or if both gonopores are visible. This genus was noted at the Hanford Reach of the Columbia River (Becker and Dauble 1979).

\section{Family Piscicolidae}

The North American Piscicola milneri (Verrill) and the Eurasian Piscicola geometra (Linnaeus) have similar geographic distributions in North America. Their external characteristics overlap, suggesting that they are the same species (Moore and Meyer 1951, Holmquist 1975). Williams and Burreson (2006) noted that "no differences were seen externally or internally between the morphology of $P$. geometra and $P$. milneri examined," although of the 9 characters examined, there was no mention of the annular placement of the gonopores that Davies and Govedich (2001) used as identification criteria. Based on molecular analysis for a single location in Quebec, Williams and Burreson (2006) stated that "all specimens in North America should be considered as P. milneri, with the exception of 3 specimens of $P$. geometra collected from German carp, Cyprinus carpio carpio, that may have been introduced with fish (Moore 1898)." Based on annular placement of gonopores, Piscicola geometra was tentatively identified at RM 562, 563, 571, and
576, and in Lake Walcott. Piscicola milneri was tentatively identified at RM 583 and below Lake Walcott Dam (Fig. 2E). Undetermined Piscicola were found at RM 475, 570, and 576. These fish leeches have numerous hosts, including the northern pike, Esox lucius, in both North America and Eurasia, whose distribution largely overlaps the 2 Piscicola distributions. In the Snake River, fish that can host these leeches include Prosopium and Salvelinus. This genus was not found at the Hanford Reach of the Columbia River (Becker and Dauble 1979). The genus Piscicola in the Snake River is a new Idaho state record.

\section{Family Erpobdellidae}

Erpobdella parva Moore is found in the northern United States and Canada (Klemm 1985). This leech was the most common leech in the Snake River between RM 203 and Lake Walcott (Fig. 2A) to depths of 7.6 m. Erpobdella parva occurred in high densities in the Snake River between Swan Falls Dam and Walter's Ferry and was found to feed on chinook salmon (Oncorhynchus tshawytscha) eggs placed in egg baskets in artificial redds (Idaho Power Company unpublished data). The specimens found in the Snake River are the typical nonpigmented E. parva, although a few specimens had a faint middorsal stripe or some speckles of dubia form (Hovingh 2004b). Erpobdella parva was identified by the number of labial eyes ( 2 pairs being normal), a characteristic that distinguishes this species from Mooreobdella microstoma (see below). If gonopore separations could be determined, a separation of more than 2 annuli would distinguish E. parva from Nephelopsis obscura. If the eyes were not visible or only a single pair of labial eyes was visible and the specimens were mature, dissection and examination of the male atrium distinguished E. parva from M. microstoma and N. obscura. The male-female gonopore separation was highly variable (Table 1). Although most of the specimens $(62.9 \%, n=124)$ were the typical Great Basin form (form D) with $31 / 2$ annuli between the gonopores, female gonopore on the furrow, there were 5 additional forms present with rare occurrences in the Great Basin (Hovingh 2004b), and 5 forms that were absent in the Great Basin (Table 1):

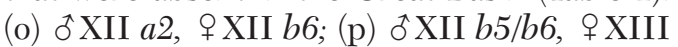

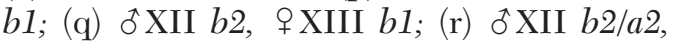
XIII $b 1$; and (s) $₫$ XII $b 2 / a 2$, + XII/XIII. The 
TABLE 1. Frequency of specimens with each type of gonopore position on Erpobdella parva. The anterior male gonopore is separated from the posterior female gonopore by $2-5$ annuli and occurs either on the annuli or in the furrow between the annuli (see Hovingh [2004b] for description of forms A-N, and text for forms o-s). Bold denotes the prevalent form. Lahontan populations, represented by the related species Erpobdella lahontana, and Steptoe populations were distinct in the Great Basin (Hovingh 2004b).

\begin{tabular}{|c|c|c|c|c|c|c|}
\hline Form & $\begin{array}{l}\text { Bear River } \\
\quad(n=87)\end{array}$ & $\begin{array}{l}\text { Weber River } \\
\quad(n=56)\end{array}$ & $\begin{array}{l}\text { Jordan River } \\
\quad(n=134)\end{array}$ & $\begin{array}{l}\text { Snake River } \\
\quad(n=124)\end{array}$ & $\begin{array}{l}\text { Lahontan } \\
(n=24)\end{array}$ & $\begin{array}{l}\text { Steptoe } \\
(n=56)\end{array}$ \\
\hline $\mathrm{A}(3 \mathrm{l} / 2)$ & & 0.018 & & & & \\
\hline B (3) & & 0.054 & 0.037 & & & \\
\hline $\mathrm{C}(4)$ & 0.149 & 0.071 & 0.090 & 0.089 & & \\
\hline $\mathrm{D}(3 \mathrm{l} / 2)$ & 0.805 & 0.829 & 0.761 & 0.629 & & \\
\hline $\mathrm{E}(3)$ & 0.034 & & 0.104 & 0.056 & & \\
\hline $\mathrm{F}(21 / 2)$ & 0.011 & & & & & \\
\hline $\mathrm{G}(4)$ & & 0.018 & & 0.016 & & \\
\hline $\mathrm{H}(5)$ & & & & 0.016 & 0.042 & \\
\hline I (4 1/2) & & & & 0.008 & 0.208 & \\
\hline $\mathrm{J}(4)$ & & & 0.007 & 0.032 & 0.042 & 0.071 \\
\hline $\mathrm{K}(3 \mathrm{l} / 2)$ & & 0.018 & & 0.056 & & 0.018 \\
\hline $\mathrm{L}(5)$ & & & & & 0.708 & \\
\hline $\mathrm{M}(4 \mathrm{l} / 2)$ & & & & & & 0.054 \\
\hline $\mathrm{N}(4)$ & & & & & & 0.821 \\
\hline$o(2)$ & & & & 0.008 & & \\
\hline $\mathrm{p}(21 / 2)$ & & & & 0.016 & & \\
\hline$q(3)$ & & & & 0.008 & & \\
\hline $\mathrm{r}(31 / 2)$ & & & & 0.008 & & \\
\hline s $(3)$ & & & & 0.056 & & \\
\hline
\end{tabular}

TABLE 2. Frequency of specimens with each type of gonopore position on Mooreobdella microstoma. Form denotes number of annuli between gonopores. Male gonopore in furrow (f) or on annulus (a). Bold denotes major frequency. Form 4(a) is characteristic of Mooreobdella tetragon in the coastal drainages of the eastern United States. The eastern North America (N.A.) specimens were from the USNM 49416 (4) from Illinois and USNM 46296 (5) from Mississippi.

\begin{tabular}{lccccc}
\hline Form & $\begin{array}{c}\text { Snake River } \\
(n=73)\end{array}$ & $\begin{array}{c}\text { Lahontan } \\
(n=37)\end{array}$ & $\begin{array}{c}\text { Klamath } \\
(n=19)\end{array}$ & $\begin{array}{c}\text { Great Plains } \\
(n=22)\end{array}$ & $\begin{array}{c}\text { Eastern N.A. } \\
(n=9)\end{array}$ \\
\hline $3(\mathrm{f})$ & 0.041 & $\mathbf{0 . 5 9 5}$ & $\mathbf{0 . 7 8 9}$ & $\mathbf{0 . 7 7 3}$ & $\mathbf{1 . 0 0 0}$ \\
$31 / 2(\mathrm{a})$ & 0.082 & 0.027 & 0.227 & \\
$31 / 2(\mathrm{f})$ & 0.110 & 0.054 & 0.158 & & \\
$4(\mathrm{f})$ & 0.164 & 0.324 & & & \\
$4(\mathrm{a})$ & $\mathbf{0 . 3 1 5}$ & & & & \\
$41 / 2(\mathrm{a})$ & 0.288 & & & & \\
\hline
\end{tabular}

major position of the male gonopore on furrow ôXII b1/b2, representing Erpobdella lahontana from the Lahontan basin and the Erpbodella parva from Steptoe basin in Nevada, was not present in the Snake River population (Table 1), suggesting that these populations have a history of isolation (Hovingh 2004b).

Mooreobdella microstoma Moore is associated with the Mississippi River basin and north of the Ohio River to the Lake Erie-St. Lawrence River in Ontario and Quebec (Sawyer and Shelly 1976, Klemm 1985; Fig. 3B) and in a drainage-dependent pattern in the western United States (Fig. 3A). Mooreobdella microstoma was the 2nd most numerous leech species in the Snake River, found in RM 246-346 and RM 448-588 to a depth of $15 \mathrm{~m}$ (Fig. 2B). It has not been found above Shoshone Falls in the upper Snake River or in the Bonneville Basin of Utah. Table 2 shows variations in the gonopore positions of Mooreobdella microstoma. The prevalent form in the western United States has the $\delta$ and $q$ gonopores in the furrows separated by 3 annuli, a form least abundant in the Snake River populations and the only form in eastern North America. Additional differences in gonopores were noted: (1) separated by $31 / 2$ annuli with $q$ gonopore in furrow; (2) separated by $31 / 2$ annuli with $\delta$ gonopore in furrow; (3) separated by 4 annuli on the furrow; (4) separated by 4 annuli on the annuli that identifies $M$. tetragon Sawyer and Shelley, whose distribution in the eastern coastal region is shown in Fig. 3B; and 

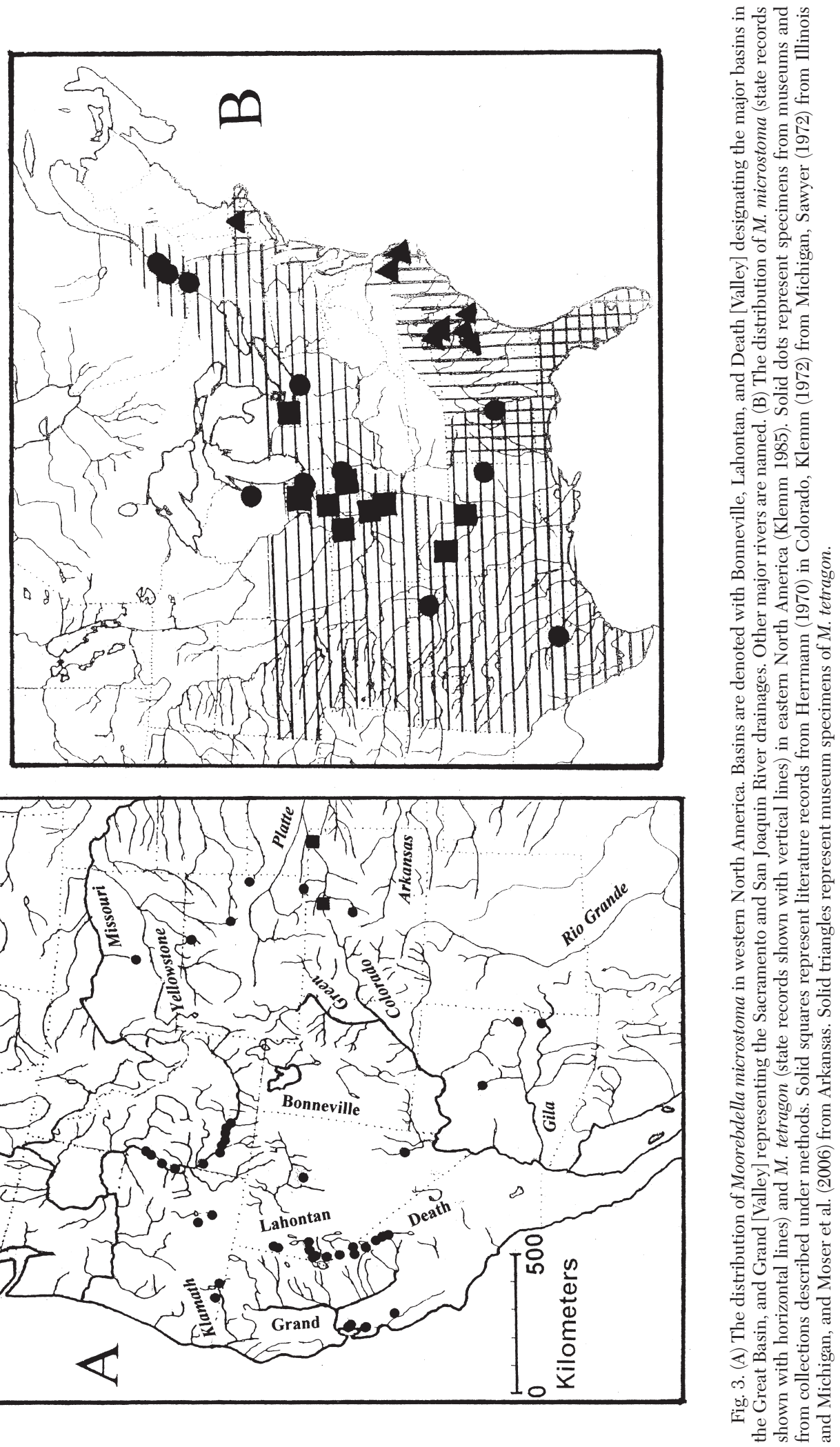


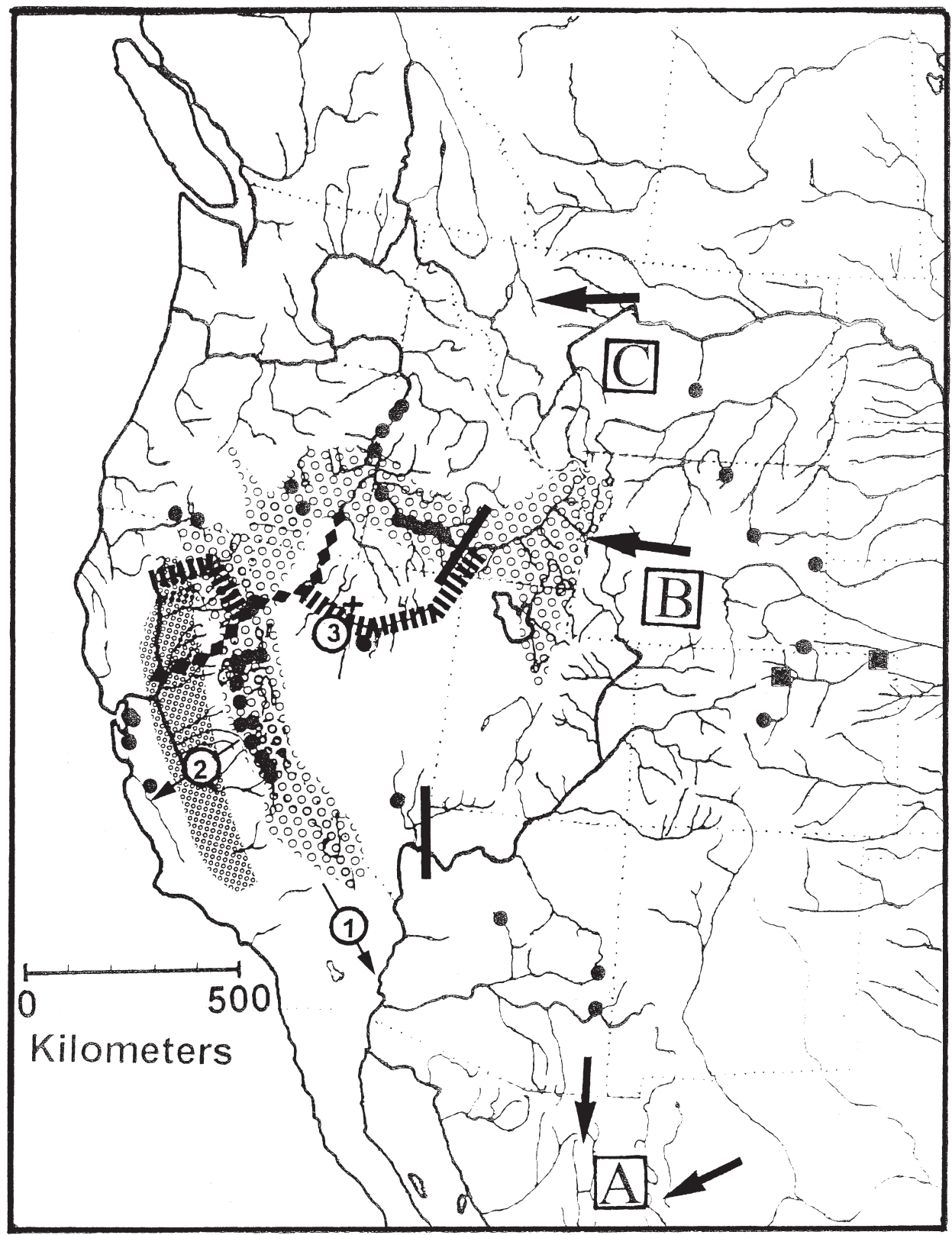

Fig. 4. Paleodrainage proposals of the Snake River based on fossil and extant aquatic fauna overlaying the distribution locations of Mooreobdella microstoma from Figure 3A. Fine stippling indicates late Miocene and Pliocene events associated with the Snake River; coarse stippling indicates late Pliocene and Pleistocene events after Taylor (1966, 1985) superimposed on the Mooreobdella microstoma distribution in western North America. Two additional events are shown: the route of connecting diamonds between eastern Oregon and Grand Valley, California (Wheeler and Cook 1954), which is supported in part by Hershler and Liu (2004); and the route of a series of bars between northern California and southern Idaho for microtine rodents (Repenning et al. 1995). The long bars across the Snake River and the Colorado River are barriers to upstream movements of aquatic fauna. Arrow \# 1 represents the lower Colorado River and the Mojave-Death Valley route, closed by 4 Ma. Arrow \#2 represents the Mono Basin and the San Joaquin Basin route, closed by 3.2 Ma. Site \#3 is the Carico Basin population of M. microstoma (dot) and Humboldt River site of Valvata utahensis shells (+). Breaches in the continental divide for transference of aquatic fauna are shown for the southern route (A), the midcontinent route $(B)$, and the northern route $(\mathrm{C})$. The arrows do not imply unidirectional movement, but movement in either direction. 
(5) separated by $41 / 2$ annuli with the $\delta$ gonopore on the annuli. Three of these variations are shared with the Lahontan Basin and 2 variations are unique in the western United States.

Species abSEnt in the SNaKe River.-Several species of leeches have not been reported from the Snake River but were found in the Columbia River drainages: the fish leeches Myzobdella lugubris and Cystobranchus (formerly Piscicola) salmositicus were found in the Hanford Reach (Becker and Dauble 1979) and M. lugubris in the Weiser River drainage (W.H. Clark unpublished observation). Erpobdella anoculata, a southern California species, was found in the Deschutes River tributary of the Columbia River in Oregon (USNM 36874, 36938). Other species not found in the main Snake River in this study, but found in its tributaries, include Placobdella ornata, P. papillifera, Haemopis marmorata, H. lateromaculata, Erpobdella punctata, and Nephelopsis obscura (Hovingh unpublished data). Erpobdella punctata was listed from Wide Rapids in the Snake River near Weiser (Stanford 1942; no voucher material present) and at the Hanford Reach of the Columbia River (Becker and Dauble 1979).

Possible LeECH InTRODUCTIONS.-The distribution of leeches in the Snake River may be the result of recent introductions. River Miles 580-590 below the Shoshone Falls barrier and Lake Walcott Reach above Shoshone Falls contain the fish leeches Actinobdella inequiannulata (sucker leech) and Piscicola sp. (also found near RM 470). Shoshone Falls is the major barrier for fish movement between the Columbia River fauna and the Bonneville Basin and upper Snake River fauna (Smith 1978), with these 2 upper regions lacking in fish leech fauna. Fish introductions have occurred since the early 1900s (see Margaritifera in Hovingh 2004a), and there are now 140 aquaculture facilities between Twin Falls and Hagerman. The presence of Myzobella lugubris in the Provo River (Winger et al. 1972) can be explained by fish transport to Utah Lake. Cystobranchus salmositica was found on rainbow trout at a commercial fish farm in Utah (Jones and Hammond 1960), and its location in the Snake River tributaries of Deer Creek (ALBRCIDA 51112) and Rock Creek (ALBRCIDA 51088) may indicate transport by introduced trout. However, $C$. salmositica is found in the west coast streams from California to British Columbia where it parasitizes salmon and is readily found below salmon fish hatcheries (Becker and Katz 1965, Burreson et al. 2005).

ZOOGEOGRAPHICAL SIGNIFICANCE OF MOOREOBDELLA MICROSTOMA IN THE WESTERN UNITED STATES. - The finding of Mooreobdella microstoma in the Snake River suggests ancient connections of many hydrological basins including the Gila and Salt rivers (Arizona) and the White River (Nevada) of lower Colorado River; the Monterey Bay drainage of Salina River and San Francisco Bay drainages near Santa Clara and Oakland (California); the Klamath River basin and Malheur Basin (Oregon); the Smoke Creek desert, Truckee, Carson, Walker, Mono Lake, and Owens drainages in the western Great Basin (Nevada, California); and the Carico Basin/Crescent Valley drainage of the Humboldt River in the central Great Basin in Nevada (Fig. 3A). This distribution is very similar to the "fish hook" distribution that describes the geographical pattern for mollusks and fish (Miller 1965, Taylor 1966, 1985, Taylor and Bright 1987).

Figure 4 represents paleodrainage proposals that may have influenced this distribution. The coarse stippling indicates a pattern between Grand Valley of California and the Snake River that was in place in the late Miocene (see Figs. 10, 15 in Taylor 1985) and Pliocene (see Fig. 5 in Taylor 1985), while the fine stippling indicates the pattern in the late Pliocene and early Pleistocene when interconnections of drainages occured over time and were not continuous, resulting in many endemic and disjunct populations (Fig. 4).

The distribution of the extant leech Mooreobdella microstoma has 3 variations to the "fish hook" pattern. First, there is a lower Colorado River (Gila and Virgin river tributaries) connection between the lower Colorado River and the coarse-stippled region (Fig. 4, \#1) that resulted in fish movement between southern California and Arizona (Minckley et al. 1986, Smith et al. 2002). This connection was closed by $4 \mathrm{Ma}$ (Brown and Rosen 1995). A barrier occurred in the Colorado River above the Virgin River preventing any leech movement into the drainages of the upper Colorado and Green rivers (Fig. 4).

Second, colonization of the Snake River was by upstream movement as shown by Mooreobdella microstoma distribution in the Snake River below the Shoshone Falls barrier. Upstream 
movement was proposed for the gastropod Vorticifex effusa, which ranges above Shoshone Falls to Goose Creek but not in the upper reaches of Snake River (see Fig. 22 in Taylor 1985). Shoshone Falls is a barrier to any $M$. microstoma colonization of the eastern Great Basin, the upper Snake River, and the Green River (Colorado River basin) from the lower Snake River (Fig. 4).

Third, Mooreobdella microstoma in the Humboldt River drainage in Carico Basin shows a relict population (site \#3, Fig. 4). A large, mid-Pleistocene lake occurred in the western Great Basin (Reheis et al. 2002) that would affect leech habitats either by allowing colonization of the many presently closed basins or by preventing colonization near the high-energy shorelines of large lakes. Mooreobdella microstoma does not occur in any of the interior basins of Nevada, although 4 other erpobdellid leeches occur in selected interior basins (Hovingh 2004b). The Carico Basin population could have moved upstream via the route of the Snake River in Lahontan Basin (Repenning et al. 1995). However, M. microstoma has not colonized the upper Snake River, suggesting movement after $4 \mathrm{Ma}$ when the Snake River formed its present course and when the Humboldt River flowed through Smoke Creek desert (Benson and Peterman 1995). The finding of Valvata utahensis shells near site \#3 (denoted as "+" in Fig. 4) suggests that this gastropod utilized the paleo Snake River route upstream from the western Great Basin or downstream from Bonneville Basin and upper Snake River. This gastropod has not been found in the Oregon basins, a big missing link in the proposed "fish hook" pattern for this species (see Fig. 16 in Taylor 1985). The distribution of M. microstoma would suggest that the upper Snake River to Virgin River through the Bonneville Basin route is not necessary to explain the distribution of fish (Smith et al. 2002), as the fish could as well have colonized within the circuitous "fish hook."

The presence of Mooreobdella microstoma in drainages of San Francisco Bay and Monterey Bay (central California) suggests affinities to the late Miocene and early Pliocene fine-stippled region (Fig. 4). Alternatively, the drainages of the Grand Valley during the Pliocene crossed the ancestral Sierra Nevada. One route (Fig. 4, \#2), from Mono Lake to the San Joaquin River, was breached by 3.2 Ma (Smith et al. 2002).
The Mooreobdella microstoma populations in the western United States are separated from the eastern populations by the continental divide. There have been 3 proposed routes of aquatic fauna transferring across the divide: (1) the southern route between California and Texas through Mexico (Fig. 4A), (2) the mid-continental route across Wyoming (Fig. $4 \mathrm{~B}$ ), and (3) the northern continental route in Montana (Fig. 4C; Hansen 1975, 1985, Taylor 1985, 1988, Minckley et al. 1986, Smith and Miller 1986). The presence of M. microstoma in the tributaries of the Missouri River in Montana, Wyoming, and Colorado suggests opportunities to colonize in either direction across the continental divide.

Mooreobdella microstoma can be characterized as a warm-temperate species in eastern North America. This species has occupied only to a very limited extent the region that was formerly occupied by the Wisconsinan glacier in Illinois to New York, suggesting that (1) the new aquatic habitats created by the regressing glaciers may not be suitable habitat; (2) this species has slow mobility; (3) climatic conditions do not allow for M. microstoma in northern environs, as suggested for fish at the mid-continental route (Hansen 1985); and (4) other erpobdellid leeches were more aggressive in post-glacial colonization and outcompeted M. microstoma. Mooreobdella microstoma has occupied Pleistocene refugia in the western Great Basin at elevations above $1400 \mathrm{~m}$, a suggested level of the very large mid-Pleistocene lake (Reheis et al. 2002). The absence of M. mooreobdella along the divide routes may be explained by climatic events, either overly cold or, in the warm reaches, overly arid conditions.

The presence of both M. microstoma and Erpobdella parva in the Snake River is unique in the western United States. While we suggested above that M. microstoma arrived in the Snake River by upstream movements, $E$. parva arrived from the upper Snake River and Bonneville Basin populations moving downstream. There are very few populations of $E$. parva farther west, and this species occurs widely in the upper reaches of the Snake River and Bonneville Basin (Hovingh 2004b). Both species colonized the middle Snake River after the Bonneville Flood $14.5 \mathrm{Ka}$. It is suggested that the confinement of M. microstoma to the deeper reaches of the Snake River (collected only by sampling as discussed in the 
methods) may be explained by avoidance of competition with E. parva, the only erpobdellid leech found in shoreline populations (Hovingh unpublished data).

\section{Conclusions}

Eight species of leeches were found in the Snake River below Shoshone Falls. Erpobdella parva and Mooreobdella microstoma were the most widely distributed leeches. Both species had highly variable gonopore positions. Mooreobdella microstoma distribution suggests the presence of this species in the western United States since the late Miocene following the proposed "fish hook" schemes, with connections between the lower Colorado River and the Snake River below Shoshone Falls to the Grand Valley of California and to the western Great Basin. The Snake River M. microstoma showed variations in the gonopore positions that did not occur in other western populations. The volcanic and flood events certainly impacted the benthic organism, with the Bonneville Flood totally purging all fauna from the main channel. Each geological event may have created a new ecological cycle with different assemblages of species.

\section{ACKNOWLEDGMENTS}

The authors wish to thank K. King and J.R. Zumberge (Wyoming Department of Environmental Quality), P. Spindler (Arizona Department of Environmental Quality), R.W. Wisseman (Aquatic Biology Associates, Inc.), and K. Lunde and S. McKown for sharing their specimens. These contributions form the basis of this paper. We also thank W. Moser (USNM), J. Madill and J.-M. Gagnon (CMN), and D. Rosenberg (ANSP) for providing facilities at the U.S. National Museum, the Canada Museum of Nature, and the Academy of Natural Sciences at Philadelphia. Thanks to P. Groves and B. Alcorn (Idaho Power Company) for observations of leech predation on fish eggs. R.W. Davies identified the Myzobdella specimen. We appreciate the comments of 2 anonymous reviewers and the editor M.C. Belk.

\section{Literature Cited}

Becker, C.D., AND D.D. Dauble. 1979. Records of piscivorus leeches (Hirudinea) from the central Columbia River, Washington State. Fishery Bulletin 76:926-931.
Becker, C.D., and M. Katz. 1965. Distribution, ecology, and biology of the salmonid leech Piscicola salmositica (Rhynchobdella: Piscicolidae). Journal of the Fisheries Research Board of Canada 22:1175-1195.

BEnito, G., AND J.E. O'ConNOR. 2003. Number and size of the last-glacial Missoula floods in the Columbia River valley beteween the Pasco Basin, Washington, and Portland, Oregon. Geological Society of America Bulletin 115:624-638.

Benson, L., And Z. Peterman. 1995. Carbonate deposition, Pyramid Lake subbasin, Nevada: 3 . The use of ${ }^{87} \mathrm{Sr}$ values in carbonate deposits (tufas) to determine the hydrologic state of paleolake systems. Palaeogeography, Palaeoclimatology, Palaeoecology 119:201-213.

Brown, W.J., AND M.R. Rosen. 1995. Was there a PliocenePleistocene fluvial-lacustrine connection between Death Valley and the Colorado River? Quaternary Research 43:286-296.

Burreson, E.M., J.E. Light, and J.I. Williams. 2005. Redescription of Cystobranchus virginicus (Hoffman, 1964) and Cystobranchus salmositicus (Meyer, 1946) (Hirudinida: Piscicolidae) from freshwater fishes in North America. Comparative Parasitology 72:157165 .

Christionsen, R.L., and R.S. Yeats. 1992. Post-Laramide geology of the U.S. Cordilleran region. Pages 261-406 in B.C. Burchfiel, P.W. Lipman, and M.L. Zoback, editors, The Cordilleran Orogen: conterminous U.S. Geological Society of America, The Geology of North America v. G-3, Boulder, CO.

Clark, W.H., B.M. Bean, M.A. Stephenson, and A.J. FosTER. 2005. Snake River aquatic macroinvertebrate and ESA snail sampling: 2004. Section 10 permit PRT\#799558 report. Idaho Power Company, Boise.

Cummings, M.L., J.G. Evans, M.L. Ferns, and K.R. Lees. 2000. Stratigraphic and structural evolution of the middle Miocene synvolcanic Oregon-Idaho graben. Geological Society of America Bulletin 112:668-682.

Davies, R.W., AND F.R. Govedich. 2001. Annelida: Euhirudinea and Acanthobdellidae. Pages 465-504 in J.H. Thorp and A.P. Covich, editors, Ecology and classification of North American freshwater invertebrates. Academic Press, San Diego, CA.

Fore, L.S., AND W.H. Clark. 2005. Statistical power comparison of two sampling protocols for riverine snails. Northwest Science 79:91-98.

GRAFE, C.S., EDITOR. 2002. Idaho River Ecological Assessment Framework: an integrated approach. Idaho Department of Environmental Quality, Boise.

Hansen, W.R. 1975. The geologic story of the Uinta Mountains. United States Geological Survey Bulletin 1291.

1985. Drainage development of the Green River basin in southwestern Wyoming and its bearing on fish biogeography, neotectonics, and paleoclimates. Mountain Geologist 22:192-204.

HaYden, G.A., J.P. Shannon, K.P. Wilson, and D.W. Blinn. 2003. Benthic community structure of the Green and Colorado rivers through Canyonlands National Park, Utah, USA. Southwestern Naturalist 48:23-35.

HerrmanN, S.J. 1970. Systematics, distribution, and ecology of Colorado Hirudinea. American Midland Naturalist 83:1-37.

Hershler, R., AND H.-P. LiU. 2004. A molecular phylogeny of aquatic gastropods provides a new perspective on biogeographic history of the Snake River region. Molecular Phylogenetics and Evolution 32:927-937. 
HolmQuist, C. 1975. Lakes of northern Alaska and northwestern Canada and their invertebrate fauna. Zoologische Jahrbücher, Abteilung für systematik Ökologie und Geographie der Tiere 102:333-484.

Hooper, P.R., G.B. Binger, and K.R. Lees. 2002. Ages of the Steens and Columbia River flood basalt and their relationship to extension-related calc-alkalic volcanism in eastern Oregon. Geological Society of America 114: $43-50$.

Hovingh, P. 2004a. Intermountain freshwater mollusks, USA (Margaritifera, Anodonta, Gonidea, Valvata, Ferrissia): geography, conservation and fish management implications. Monographs of the Western North America Naturalist 2:109-135.

2004b. Erpobdella (Dina) parva complex (Annelida: Hirudinea: Arhynchobdellida: Erpobdellidae): additional description of Erpobdella parva, E. dubia, and E. lahontana and taxonomic revision. Hydrobiologia 517:89-105.

IRIZARRY, R.A. 1999. Endangered Species Act investigations, Lake Walcott, Idaho, June 1997. U.S. Bureau of Reclamation, Boise, ID.

Jarkett, R.D., AND H.E. Malde. 1987. Paleodischarge of the late Pleistocene Bonneville Flood, Snake River, Idaho, computed from new evidence. Geological Society of America Bulletin 99:127-134.

Johnson, P.T.J., K.B. Lunde, E.M. Thurman, E.G. Ritchie, S.N. Wray, D.R. Sutherland, J.M. Kapfer, et al. 2002. Parasite (Ribeiroia ondatrae) infection linked to amphibian malformations in the western United States. Ecological Monographs 72:151-168.

Jones, K.L., AND D.M. Hammond. 1960. A study of the parasites from rainbow trout of a commercial fish farm in Cache Valley, Utah. Utah Academy of Science, Arts, and Letters Proceedings 37:157-158.

Jordan, S., D.K. Shiozawa, and J.M. Schmid-Araya. 1999. Benthic invertebrates of a large, sandy river system: the Green and Colorado Rivers of Canyonlands National Park, Utah. Archiv für Hydrobiologie 147:91-127.

KLemm, D.J. 1972. The leeches (Annelida: Hirudinea) of Michigan. Michigan Academician 4:405-444.

. 1985. Freshwater leeches (Annelida: Hirudinea). Pages 70-194 in D.J. Klemm, editor, A guide to the freshwater Annelida (Polychaeta, naidid and tubificid Oligochaeta, and Hirudinea) of North America. Kendall/Hunt, Dubuque, IA.

Klemm, D.J., B.A. Daniels, W.E. Moser, and R.J.G. LESTER. 2003. Biology of the leech Actinobdella inequiannulata Moore, 1901 (Annelida: Hirudinea: Rhynchobdellida: Glossiphoniidae), parasitic on the white sucker, Catostomus commersoni Lacepède, 1803, and the longnose sucker, Catostomus catostomus Forster, 1773, in Algonquin Provincial Park, Ontario, Canada. Comparative Parasitology 70:120-127.

Kuntz, M.A., E.C. SPIKER, M. Rubin, D.E. Champion, AND R.H. LEFEBVRE. 1986. Radiocarbon studies of the latest Pleistocene and Holocene lava flows of the Snake River Plain, Idaho: data, lessons, interpretations. Quaternary Research 25:163-176.

Lanphere, M.A., D.E. Champion, R.L. Christiansen, G.A. IZETT, AND J.D. OBRADOVICH. 2002. Revised ages for tuffs of the Yellowstone Plateau volcanic field: assignment of the Huckleberry Ridge tuff to a new geomagnetic polarity. Geological Society of America Bulletin 114:559-568.
Malde, H.E. 1965. Snake River Plain. Pages 255-363 in H.E. Wright, Jr., and D.G. Frey, editors, The Quaternary of the United States. Princeton University Press, Princeton, NJ.

1982. The Yahoo clay, a lacustrine unit impounded by McKinney basalt in the Snake River Canyon near Bliss, Idaho. Pages 617-628 in B. Bonnichsen and R.M. Breckenridge, editors, Cenozoic Geology of Idaho. Idaho Bureau of Mines and Geology Bulletin 26.

1991. Quaternary geology and structural history of the Snake River Plain, Idaho and Oregon. Pages 251-281 in R.B. Morrison, editor, Quaternary nonglacial geology: conterminous U.S. Geological Society of America, The Geology of North America v. K-2. Boulder, CO.

McCabe, G.T., S.A. Hinton, R.L. Emmett, and B.P. SanFORD. 1997. Benthic invertebrates and sediment characteristics in main channel habitats in the lower Columbia River. Northwest Science 71:45-55.

MCPhail, J.D., AND C.C. LindSEy. 1986. Zoogeography of the freshwater fishes of Cascadia (the Columbia System and rivers north to the Stikine). Pages 615-637 in C.H. Hocutt and E.O. Wiley, editors, The zoogeography of North American freshwater fishes. John Wiley \& Sons, Inc., New York.

MiLLER, R.R. 1965. Quaternary freshwater fishes of North America. Pages 569-581 in H.E. Wright, Jr., and D.G. Frey, editors, The Quaternary of the United States. Princeton University Press, Princeton, NJ.

Minckley, W.L., D.A. Hendrickson, and C.E. Bond. 1986. Geography of western North American freshwater fishes: description and relationships to intracontinental tectonism. Pages 519-613 in C.H. Hocutt and E.O. Wiley, editors, The zoogeography of North American freshwater fishes. John Wiley \& Sons, Inc., New York.

Moore, J.P., AND M.C. Meyer. 1951. Leeches (Hirudinea) from Alaskan and adjacent waters. Wasmann Journal of Biology 9:11-77.

Morgan, L.A., And W.C. McIntosh. 2005. Timing and development of the Heise volcanic field, Snake River Plain, Idaho, western USA. Geological Society of America Bulletin 117:288-306.

Moser, W.E., D.J. Klemm, D.J. Richardson, B.A. Wheeler, S.E. Trauth, and B.A. Daniels. 2006. Leeches (Annelida: Hirudinida) of northern Arkansas. Journal of the Arkansas Academy of Science 60:84-95.

O'CONNER, J.E. 1993. Hydrology, hydraulics, and geomorphology of the Bonneville Flood. Geological Society of America Special Paper 274. Boulder, CO.

Oviatt, C.G., D.R. CurReY, and D. Sack. 1992. Radiocarbon chronology of Lake Bonneville, eastern Great Basin, USA. Palaeogeography, Palaeoclimatology, Palaeoecology 99:225-241.

Peck, D.V., D.K. Averill, J.M. Lazorchak, and D.J. Klemm, EDITORs. 2003. Environmental Monitoring and Assessment Program-Surface waters: western pilot study field operations manual for non-wadeable rivers and streams. U.S. Environmental Protection Agency, Corvallis, OR.

Pierce, K.L., And L.A. Morgan. 1992. The track of the Yellowstone Hot Spot: volcanism, faulting, and uplift. Pages 1-53 in P.K. Link, M.A. Kuntz, and L.B. Platt, editors, Regional geology of eastern Idaho and western Wyoming. Geological Society of America Memoir 179. Boulder, CO. 
Reheis, M.C., A.M. Sarna-Wojcicki, R.L. Reynolds, C.A. Repenning, And M.D. Mifflin. 2002. Pliocene to Middle Pleistocene lakes in the western Great Basin: ages and connections. Pages 53-108 in R. Hershler, D.B. Madsen, and D.R. Currey, editors, Great Basin aquatic systems history. Smithsonian Contributions to the Earth Sciences 33, Smithsonian Institution Press, Washington, DC.

Rempel, L.L., J.S. Richardson, and M.C. Healy. 1999. Flow refugia for benthic macroinvertebrates during flooding of a large river. Journal of the North American Benthological Society 18:34-48.

Repenning, C.A., T.R. Weasma, and G.R. Scott. 1995. The early Pleistocene (latest Blancan-earliest Irvingtonian) Froman Ferry fauna and history of the Glenns Ferry Formation, southwestern Idaho. United States Geological Survey Bulletin 2105.

Richmond, G.M., R. Fryxell, G.E. Neff, and P.L. Weis. 1965. The Cordilleran ice sheet of the northern Rocky Mountains, and related Quaternary history of the Columbia Plateau. Pages 231-242 in H.E. Wright, Jr., and D.G. Frey, editors, The Quaternary of the United States. Princeton University Press, Princeton, NJ.

SADLER, J.L., AND P.K. LinK. 1996. The Tuana gravel: early Pleistocene response to longitudinal drainage of a late-stage rift basin, western Snake River Plain, Idaho. Northwest Geology 26:46-62.

SAWYER, R.T. 1972. North American freshwater leeches, exclusive of the Piscicolidae with a key to all species. Illinois Biological Monographs 46. University of Illinois Press, Urbana.

1986. Leech biology and behaviour. Oxford Science Publications, Oxford, U.K.

SAWYER, R.T., AND R.M. ShelLEy. 1976. New records and species of leeches (Annelida: Hirudinea) from North and South Carolina. Journal of Natural History 10: 65-97.

Sмith, G.R. 1978. Biogeography of intermountain fishes. Pages 17-42 in K.T. Harper and J.L. Reveal, editors, Intermountain biogeography: a symposium, Great Basin Naturalist Memoirs 2.

Smith, G.R., T.E. Dowling, K.W. Gobalet, T. Lugaski, D.K. ShiozaWa, and R.P. Evans. 2002. Biogeography and timing of evolutionary events among Great Basin fishes. Pages 175-234 in R. Hershler, D.B. Madsen, and D.R. Currey, editors, Great Basin aquatic systems history. Smithsonian Contributions to the Earth Sciences 33, Smithsonian Institution Press, Washington, DC.

SMith, M.L., AND R.R. Miller. 1986. The evolution of the Rio Grande Basin as inferred from its fish fauna. Pages 457-484 in C.H. Hocutt and E.O. Wiley, editors, The zoogeography of North American freshwater fishes. John Wiley \& Sons, Inc., New York.
Stanford, L.M. 1942. Preliminary studies in the biology of Snake River. Doctoral dissertation, University of Washington, Seattle.

TAYLOR, D.W. 1960. Distribution of the freshwater clam Pisidium ultramontanum: a zoogeographic inquiry. American Journal of Science (Bradley Volume) 258A:325-334.

1966. Summary of North American Blancan nonmarine mollusks. Malacologia 4:1-172.

1985. Evolution of freshwater drainages and molluscs in western North America. Pages 265-321 in C.I. Smiley, editor, Late Cenozoic history of the Pacific Northwest: interdisciplinary studies on the Clarkia Fossil Beds of northern Idaho. Pacific Division of the American Association for the Advancement of Science, San Francisco, CA.

1988. Aspects of freshwater mollusc ecological biogeography. Palaeogeography, Palaeoclimatology, Palaeoecology 62:511-576.

TAYlor, D.W., AND R.C. BRIGHT. 1987. Drainage history of the Bonneville Basin. Pages 239-256 in R.S. Kopp and R.E. Cohenou, editors, Cenozoic geology of western Utah: sites for precious metal and hydrocarbon accumulations. Utah Geological Association, Salt Lake City.

Wagner, H.M., C.B. Hanson, E.P. Gustafson, K.W. GOBALET, AND D.P. WHISTLER. 1997. Biogeography of Pliocene and Pleistocene vertebrate faunas of northeastern California and their temporal significance to the development of the Modoc Plateau and the Klamath Mountains Orogen. San Bernardino County Museum Association Quarterly 44:13-21.

Wheeler, H.E., AND E.R. CoOK. 1954. Structural and stratigraphic significance of the Snake River capture, Idaho-Oregon. Journal of Geology 62:525-536.

Williams, J.I., AND E.M. Burreson. 2006. Phylogeny of the fish leeches (Oligochaeta, Hirudinida, Piscicolidae) based on nuclear and mitochondrial genes and morphology. Zoologica Scripta 35:627-639.

Winger, P.V., E.J. Peters, M.J. Donahoo, J.R. Barnes, AND D.A. White. 1972. A checklist of the macroinvertebrates of the Provo River, Utah. Great Basin Naturalist 32:211-219.

Zoback, M.L., E.H. McKeE, R.J. Blakely, and G.A. Thompson. 1994. The northern Nevada rift: regional tectono-magmatic relations and middle Miocene stress. Geological Society of America Bulletin 106:371-382.

Received 20 April 2007 Accepted 31 October 2007 